\title{
Autumn to spring microbial community in the northern Baltic Sea: temporal variability in bacterial, viral and nanoflagellate abundance during the cold-water season
}

\author{
Laura Kaikkonen $^{1,2} \cdot$ Sara Enberg ${ }^{1,2} \cdot$ Jaanika Blomster ${ }^{1} \cdot$ Anne-Mari Luhtanen $^{2,3,4} \cdot$ Riitta Autio $^{3}$. \\ Janne-Markus Rintala ${ }^{1,2,5}$
}

Received: 10 March 2019 / Revised: 8 June 2020 / Accepted: 16 June 2020 / Published online: 26 June 2020

(c) The Author(s) 2020

\begin{abstract}
Marine microbial communities undergo drastic changes during the seasonal cycle in high latitude seas. Despite the dominance of microbial biomass in the oceans, comprehensive studies on the seasonal changes of microbial plankton during the complete winter period are lacking. To study the seasonal variation in abundance of the microbial community, water samples were collected weekly in the Northern Baltic Sea from October to May. During ice cover from mid-January to April, samples from the sea ice and the underlying water were taken in addition to the water column samples. Abundances of bacteria, virus-like particles, nanoflagellates, and chlorophyll $a$ concentrations were measured from sea ice, under-ice water, and the water column, and examined in relation to environmental conditions. All studied organisms had clear seasonal changes in abundance, and the sea-ice microbial community had an independent wintertime development compared to the water column. Bacteria were observed to have a key role in the biotic interactions in both ice and the water column, and the dormant period during the cold-water months (October-May) was limited to before ice formation. Our results provide the first insights into the temporal dynamics of bacteria and viruses during the whole cold-water season (October-May) in coastal high latitude seas, and demonstrate that changes in the environmental conditions are likely to affect bacterial dynamics and have implications on trophic interactions.
\end{abstract}

Keywords Bacteria $\cdot$ Baltic Sea $\cdot$ Nanoflagellates $\cdot$ VLP $\cdot$ Sea ice $\cdot$ Time series

Electronic supplementary material The online version of this article (doi:https://doi.org/10.1007/s00300-020-02700-8) contains supplementary material, which is available to authorized users.

Laura Kaikkonen

laura.m.kaikkonen@helsinki.fi

1 Ecosystems and Environment Research Programme, Faculty of Biological and Environmental Sciences, University of Helsinki, P.O. Box 65, 00014 Helsinki, Finland

2 Tvärminne Zoological Station, University of Helsinki, 10900 Hanko, Finland

3 Marine Research Centre, Finnish Environment Institute, 00790 Helsinki, Finland

4 Molecular and Integrative Biosciences, Faculty of Biological and Environmental Sciences, University of Helsinki, Helsinki, Finland

5 Present Address: Institute for Atmospheric and Earth System Research (INAR), Faculty of Science, University of Helsinki, P.O. Box 64, 00014 Helsinki, Finland

\section{Introduction}

Microbial communities undergo changes in both abundance and community composition during a seasonal cycle in high latitude seas. During winter months when autotrophic production is limited, the importance of heterotrophic production by microbes is emphasized (Moreau et al. 2010; Enberg et al. 2018). The extreme seasonality in light availability in high latitudes limits primary production and results in only a short growth season that provides biomass for higher trophic levels for the entire year (Sakshaug 2004). Together with changes in the physicochemical properties of the water column, notably the annual ice cover, planktonic communities also exhibit pronounced seasonal succession patterns (Kuosa 1991; Pinhassi and Hagström 2000; Enberg et al. 2018). To understand how communities respond to the changing environmental conditions, it is crucial to examine the seasonal variation in the microbial community. 
Given its subpolar location, seasonality is one of the key features of the Baltic Sea. A yearly ice cover extends on approximately $44 \%$ of the surface of the sea with a significant inter-annual variation in the extent and duration of the sea ice (Vihma and Haapala 2009). Baltic Sea ice is structurally similar to sea ice found in polar areas with interconnected brine pockets (Vihma and Haapala 2009) and hosts a diverse range of organisms living in the brine channels (Arrigo 2014; Thomas et al. 2017). Lower salinities in the Baltic Sea result in smaller brine volumes than in Polar sea ice, further limiting the available space (Weissenberger et al. 1992). Dissolved nutrients are concentrated within the brine pockets similarly to the salts present in the parent water, making the brine pockets an extremely nutrient concentrated habitat, with lower temperatures than in the underlying water column (Petrich and Eicken 2010). In addition to the brine channels, the under-ice water hosts a sub-ice habitat with organisms attached to or in close contact with the bottom ice (Boetius et al. 2015).

The initial microbial communities in sea ice are a result of the organisms incorporating in the brine pockets from the water column during ice formation (Gradinger and Ikävalko 1998; Rózańska et al. 2009; Eronen-Rasimus et al. 2015). Organisms may further be advected into the brine channels from the under-ice water through active brine movement (Hunt Jr et al. 2016). Given the limited space in the brine channels, Baltic Sea ice is dominated by smaller protists than Polar sea ice. The food web structure in ice thus differs from that of the water column, mainly as a result of absence of larger grazers (Krembs et al. 2000; Kaartokallio 2004; Caron et al. 2017). Heterotrophic bacteria are one of the most abundant organisms in the water column and sea ice both in terms of cell numbers and biomass (Lizotte 2003; Mock and Thomas 2005) and undergo seasonal changes in abundance and community composition (Mock et al. 1997; Pinhassi and Hagström 2000; Kaartokallio et al. 2008). Together with heterotrophic eukaryotes (Hassett et al. 2019), bacteria have a key role in nutrient recycling in ice, degrading particulate and dissolved organic matter and regulating nutrient availability (Zhou et al. 2014). Bacteria are grazed by a diverse group of nanoflagellates and other protists (Kuuppo-Leinikki 1990; Tophøj et al. 2018), which are an important link between bacteria and higher trophic levels (Azam et al. 1983).

Viral lysis is another important factor controlling bacterial abundance. High abundances of viruses have been observed in both in sea ice and the underlying water, and the number of viruses may be over tenfold to that of prokaryotic organisms (Whitman et al. 1998; Karner et al. 2001; Suttle 2005), with highest ratios in newly formed sea ice (Collins and Deming 2011). By lysing cells, viruses prevent the carbon flow to higher trophic levels, returning it to the microbial loop and controlling the nutrient and energy recycling in the water column (Wilhelm and Suttle 1999). While protistan grazing of bacteria transfers carbon to higher trophic levels, viral lysis releases carbon as dissolved organic matter, which can in some cases increase the activity of the remaining bacteria. Viruses are often very host-specific and can thus notably change the bacterial community composition. The relative importance of grazing and lysis in bacterial mortality further varies with depth and environmental conditions (Umani et al. 2010; Tsai et al. 2016). Given the key roles of microbial communities in biogeochemical cycling transferring energy and nutrients to higher trophic levels (Ejsmond et al. 2019), viral infections and shifts in community composition may have major ecological consequences (Proctor and Fuhrman 1990; Zhang et al. 2007).

Biogeochemical processes in the sea ice are important in mediating ecosystem processes also in the water column (Yakubov et al. 2019). Timing of sea-ice formation and its duration have been shown to be important for primary producers, and the vernal ice melt has an essential role for the benthic communities as organic matter sinks to the sea floor (Leu et al. 2015). Warming temperatures may have complex impacts on the phenologies of primary producers (Tedesco et al. 2019) and impact notably the size distribution of plankton communities (Daufresne et al. 2009). As increasing temperatures are expected to reduce seasonal ice cover in the Baltic Sea (Jylhä et al. 2008), the changing seasonality (Kahru et al. 2016) may therefore also affect the microbial community phenologies (Sydeman and Bograd 2009).

Given the dominance of microbial biomass in the oceans, predicting future changes in high latitude marine ecosystems requires emphasis on microbes and their temporal dynamics. Yet, proportionally few studies have addressed the succession patterns of microbial marine communities during a whole seasonal cycle, often focusing on specific taxonomic groups (Andersson et al. 1996; Pinhassi and Hagström 2000; Schauer et al. 2003; Mary et al. 2006; Iversen and Seuthe 2011; Hassett and Gradinger 2016). Comprehensive time series data on several important microbial variables have only been collected recently (Iversen and Seuthe 2011; Marquardt et al. 2016; Bunse et al. 2018), and especially viruses have been largely neglected (Sandaa et al. 2018). There is thus a pertinent need for more time series approaches to establish a baseline to observe potential shifts in marine microbial communities. Here, we study the seasonal changes in abundance of major groups of microorganisms in the water column, sea ice, and under-ice water. The focus of our investigation is on the abundance of heterotrophic bacteria, virus-like particles, and nanoflagellates from autumn to early summer. The term "microbial community" is used in this paper to describe the studied organism groups. We use the term bacteria to describe prokaryotic cells, although the observations may also include archaea. 


\section{Material and methods}

\section{Study site and sampling}

Sampling was performed weekly in the northwest coast of Gulf of Finland (Fig. 1). The study site Storfjärden (59 $51.250^{\prime} \mathrm{N}, 23^{\circ} 15.815^{\prime} \mathrm{E}$ ) is approximately $30 \mathrm{~m}$ deep, characterized by salinity of 4-6, relative exposure to winds and thus prone to sudden sea-ice break-ups. Samples were collected from a boat or on the ice from October to May, with the exceptions of 24 and 31 Dec 2012, 7 Jan 2013, 11 to $18 \mathrm{Feb} 2013$ and 22 Apr 2013 when samples could not be collected due to poor sea-ice conditions. Water samples were collected using a hose sampler with an internal diameter of $6 \mathrm{~cm}$ from 0 to $15 \mathrm{~m}$ depth (Majaneva et al. 2009). Water temperature and salinity were measured with a Falmouth Scientific NXIC CTD.

During ice cover from January to April, samples from the sea ice and the underlying water were collected in addition to the water column samples. Ice sampling was performed using a motorized CRREL-type ice-coring auger (9 cm internal diameter; Kovacs Enterprises, Roseburg, OR, USA). Ice samples were rapidly melted by crushing without filtered sea water additions as described in Rintala et al. (2014). Prior to ice sampling, snow cover on ice was measured from three random replicate samples with $1 \mathrm{~cm}$ precision using a motorized CRREL-type ice-coring auger
( $9 \mathrm{~cm}$ internal diameter; Kovacs Enterprises). Sea-ice temperatures were measured with a Testo 110 thermometer, and the bulk salinities of the melted ice samples were measured with an YSI 63 m (Yellow Springs Instruments). Under-ice water samples were obtained by submerging a bottle in a hole drilled in ice. After ice melted, we continued to sample the surface water until the end of the study period from a similar depth than the under-ice water samples. Concentrations of inorganic nutrients $\left(\mathrm{PO}_{4}, \mathrm{NH}_{4}\right.$, $\mathrm{NO}_{2}+\mathrm{NO}_{3}, \mathrm{SiO}_{4}$ ) were determined with an interval of 2 to 3 weeks from all sampled habitats using a Hitachi U-110 Spectrophotometer (Hitachi High-Technologies) according to standard seawater protocols described by Hansen and Koroleff (1999). Nutrient concentrations in ice were normalized to the average bulk salinities of melted sea ice to adjust for salinity-related variations in the nutrient concentrations.

Chlorophyll $a$ concentration was determined from two $100 \mathrm{ml}$ aliquots of sample water (ice and water) filtered on $25 \mathrm{~mm}$ Whatman GF/F filters and extracted in $94 \%$ ethanol. After being incubated in dark in room temperature for a minimum of $24 \mathrm{~h}$, the extract was filtered again through a Whatman GF/F filter and measured with a Cary Varian Eclipse spectrofluorometer. Chlorophyll $a$ concentrations were calculated according to HELCOM (1988).

Abundances of virus-like particles (VLP) and bacterial cells were determined using a CyFlow $\odot$ Cube 8 flow cytometer as per instructions of Manual of Viral Ecology

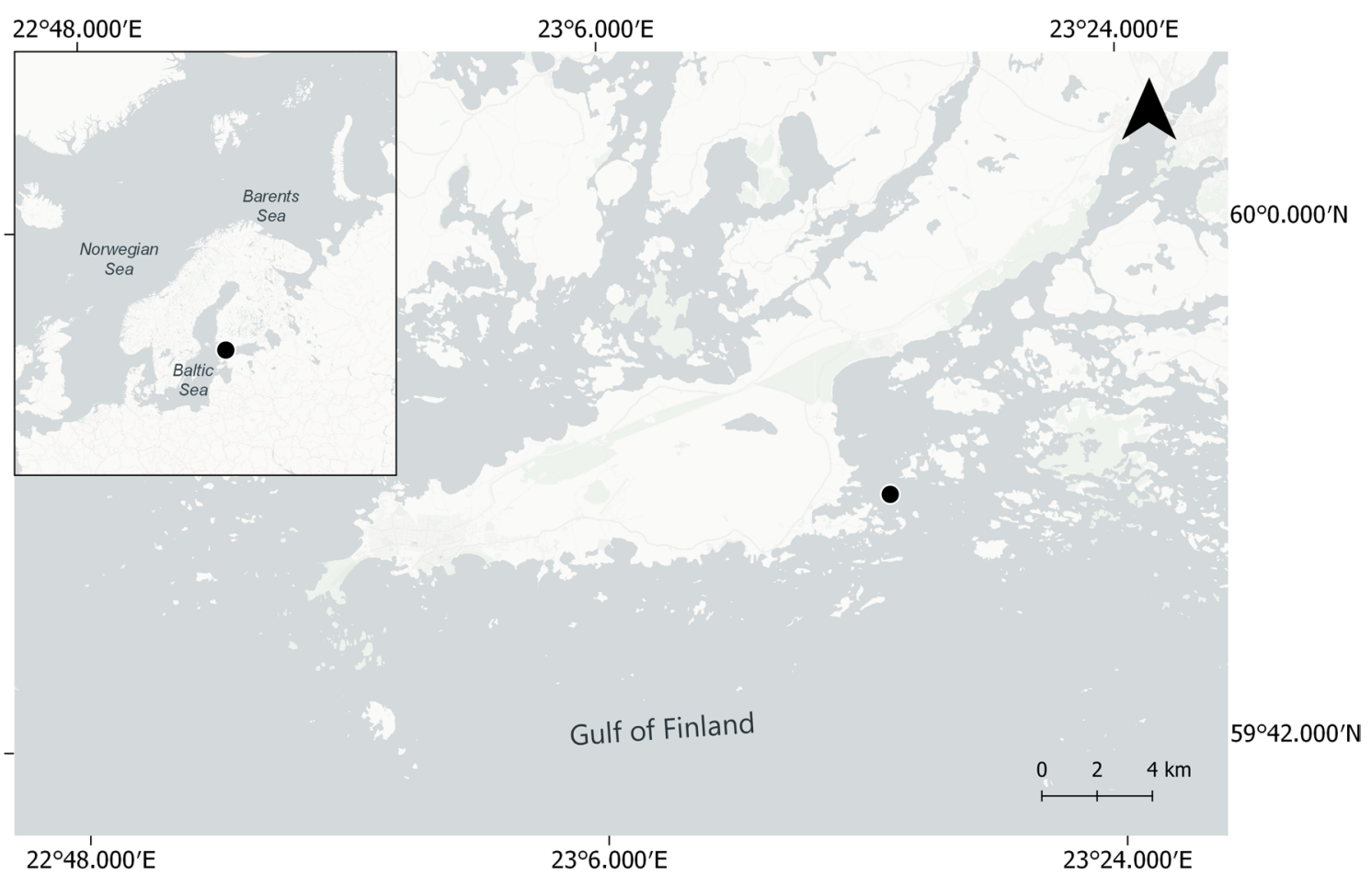

Fig. 1 Location of the sampling site in the Baltic Sea and in the Tvärminne archipelago 
(Brussaard et al. 2010). Subsamples of $1.5 \mathrm{ml}$ were obtained from all of the water and sea-ice samples and placed into plastic cryovials after which they were preserved with paraformaldehyde (final concentration $1 \%$ ). The samples were left to settle for $30 \mathrm{~min}$ before flashfreezing with liquid nitrogen and were stored at $-80{ }^{\circ} \mathrm{C}$ (Marie et al. 1999). Prior to enumeration, samples were thawed in room temperature, diluted in 1:10 in sterile TEbuffer (AppliChem GmbH, Darmstadt, Germany, pH 8) and stained for $15 \mathrm{~min}$ in the dark with SYBR Green I nucleic acid stain (final concentration $0.0036 \%$, Molecular Probes). After staining, $0.5 \mu \mathrm{m}$ fluorescent microspheres (Molecular Probes) were added into the solution for size reference. Samples were analyzed using a flow rate of $12 \mu 1 \mathrm{~min}^{-1}$. The data were acquired on a dot plot displaying green fluorescence $(488 \mathrm{~nm})$ versus side scatter signal, both on a logarithmic scale. The detection trigger was depicted as a green fluorescence. The obtained data were analyzed with a FCS Express 4-software (De Novo Software)

Bacterial production was measured using the $3 \mathrm{H}$-thymidine incorporation method (Fuhrman and Azam 1980, 1982) to examine bacterial net biomass production based on DNA synthesis. Analyses were carried out at 1 to 3 week intervals on both ice and water samples. The ice samples were prepared as described in Kaartokallio (2004). Duplicate $10 \mathrm{ml}$ subsamples and a formalin-killed blank were incubated with [methyl-3H]-thymidine at a saturation level $\left(25 \mathrm{nM}\right.$, specific activity $\left.20 \mathrm{Ci} \mathrm{mmol}^{-1}\right)$ in dark at $-0.2^{\circ}$ for $2-19 \mathrm{~h}$ according to the predicted level of activity. Incubation was stopped by adding formaldehyde and samples were processed with the standard cold-TCA extraction method using $0.2 \mu \mathrm{m}$ mixed cellulose ester filters (Advantec MFS). The filters were dissolved in InstaGel scintillation cocktail (PerkinElmer) and the incorporated radioactive thymidine was assayed with a Wallac WinSpectral 1414 liquid scintillation counter (PerkinElmer).

For nanoflagellate enumeration, a subsample of $20 \mathrm{ml}$ was taken from each water and ice sample and preserved with $1 \mathrm{ml}$ particle free $25 \%$ glutaraldehyde. Samples were stored at $+4{ }^{\circ} \mathrm{C}$. Nanoflagellates $(<10 \mu \mathrm{m})$ were enumerated with a Leitz Aristoplan epifluorescence microscope under blue light using a $100 \times$ objective magnification together with $12.5 \times$ ocular magnifications. Five to ten $\mathrm{ml}$ of sample was filtered onto $0.2 \mu \mathrm{m}$ black track etched membrane filters (Whatman) and stained with 50 to $100 \mu \mathrm{l}$ $0.033 \%$ proflavine solution (Haas 1982). A minimum of 30 cells or 50 fields of vision were counted from each sample with the accuracy of $\pm 28 \%$ at a $95 \%$ confidence interval (Lund et al. 1958). Separation of autotrophic and heterotrophic nanoflagellates was not performed systematically.

\section{Statistical analysis}

A repeated measures analysis of variance (ANOVA) was applied to test for differences between organism abundances between sampled habitats at specific sampling days. Normality checks and Levene's test were carried out and the assumptions were met. Bivariate correlations were used to examine relations between the studied organisms and environmental parameters. To account for the temporal autocorrelation in the data and to specifically remove seasonal variation in the time series, residuals were first calculated by subtracting monthly mean values from the corresponding cell abundance values and environmental data values (Chatfield 2016). Pearson's product-moment correlation analysis was then applied on the residuals to examine linear relations between the seasonally adjusted organism abundances and environmental parameters (Tsai et al. 2013). Stationarity of the residuals and absence of serial correlation were verified with autocorrelation and partial autocorrelation function plots provided by R 3.6.1 (R Core Team 2019) base package prior to correlation tests.

Due to the potentially changing direction of interactions between organisms during the seasonal cycle, we also examine the seasonal interactions between organisms in the water column while maintaining the time series structure of the data. In a time series, the value of an observation at a given point is not truly random or independent, but depends on the values of preceding time points (Borcard et al. 2018). Due to this temporal dependency and strong autocorrelation of the observations, traditional multivariate analysis techniques are not statistically adequate for studying these relations. To account for these issues, we applied a first order vector autoregressive model (VAR(1)) which allows the variables to be modeled jointly over present and past time periods. An autoregressive model using the vars package in $\mathrm{R}$ (Pfaff $2008 \mathrm{a}, \mathrm{b})$ was applied only on water sample data given the relatively small number of samples in ice, using a lag of 1 week. To examine the interactions proposed by the model, we tested how well values of one time series can be used to predict the values of another (Faust et al. 2015) by performing Granger causality tests between groups for which the model suggested significant interactions (Granger 1969). All analyses were performed with R 3.6.1 (R Core Team 2019).

\section{Results}

\section{Environmental conditions}

Winter 2012-2013 was characterized by long persisting sub-zero temperatures and ice cover from late December to mid-April. Ice formed at the sampling station between January 11th and January 14th, reaching a maximum depth 
of $52 \mathrm{~cm}$ on March 25th (Fig. 2). The ice cover melted partially between February 11th and February 18th, after which the ice was reformed and increased in depth until ice melt in April. Snow cover on the ice was relatively low throughout the study period, and varied between 0 and $3 \mathrm{~cm}$ (Fig. 2). Water temperatures decreased rapidly from October to December and remained between 0 and $1{ }^{\circ} \mathrm{C}$ from January to April (Fig. 3). A decline in salinity was observed in the under-ice water from January to April, with a minimum salinity of 2.4 pointing to a freshwater lens under the ice cover (see supplementary material in Enberg et al. 2018). The minimum salinity in the water column was 4.7 (Fig. 3). Concentrations of phosphate, silicate and mono-nitrogen oxides in the water column were highest from mid-December through March (Online Resource 1), with maximum concentrations of 0.9, (Phosphate), 26.9 (Si), 10.2 (nitrate) mmol m $\mathrm{m}^{-3}$. In ice, phosphate concentration decreased throughout the entire ice-covered period, with a minimum concentration $0.1 \mathrm{mmol} \mathrm{m}^{-3}$ (Online Resource 1).

\section{Chlorophyll $a$}

Chlorophyll $a(\mathrm{chl} a)$ concentration in the water column declined slightly in October and stayed below $3 \mu \mathrm{g} 1^{-1}$ until April, with the minimum of $0.312 \mu \mathrm{g}^{-1}$ and a maximum concentration of $10.87 \mu \mathrm{g} \mathrm{chl} a 1^{-1}$ (Fig. 4). No clear spring bloom was observed during the study period. In sea ice, bulk chlorophyll $a$ concentrations were higher than in the water column. The chl $a$ in sea ice remained low until a sudden increase in February, with chl $a$ concentration peaking at

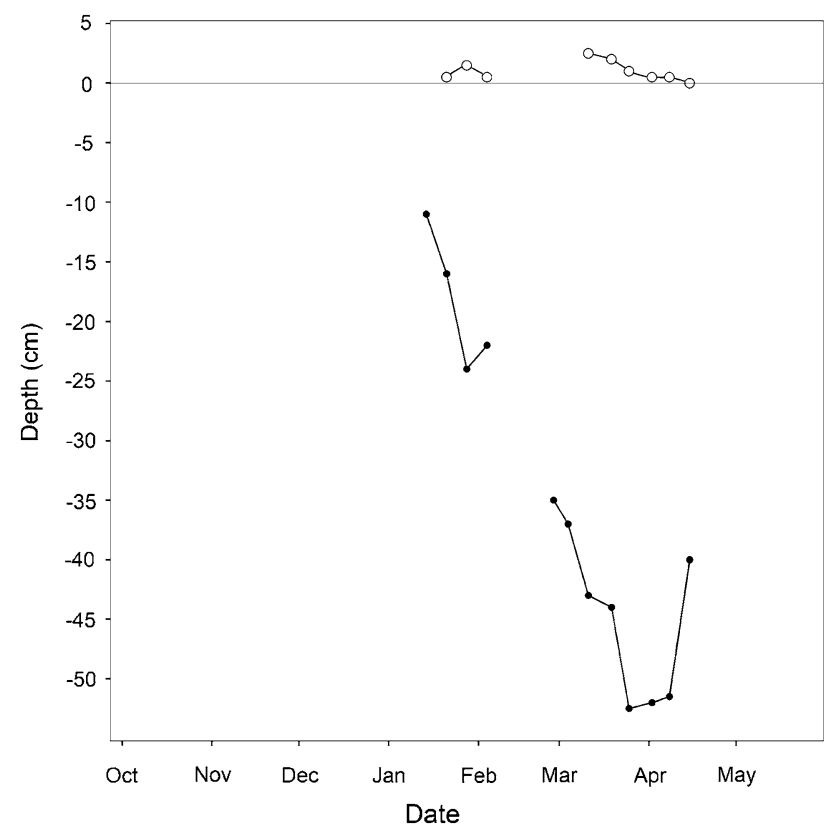

Fig. 2 Mean snow cover (white circles) and ice cover depths (black circles) at the study site. Depth of $0 \mathrm{~cm}$ denotes the ice surface
$21 \mu \mathrm{g} \operatorname{chl} a \mathrm{l}^{-1}$. This coincided with the melting and reformation of the ice field and corresponds to the maximum chlorophyll $a$ concentration observed during the study period.

\section{Seasonal changes in bacterial abundance and production}

Bacterial abundance in the water column decreased from $5 \times 10^{6}$ cells ml ${ }^{-1}$ in October to $2.2 \times 10^{6}$ cells ml $^{-1}$ in February (Fig. 5, panel a). The minimum abundance was $2-2.5 \times 10^{6}$ cells ml $^{-1}$ in March-April. After the ice melt, bacterial abundances increased, and the maximum was observed during the last sampling in late May with bacterial numbers reaching $7 \times 10^{6}$ cells $\mathrm{ml}^{-1}$. During winter, the overall bacterial abundance was $2-2.5$ million cells both in the under-ice water and the water column, but the abundance at specific sampling dates during the entire sampling period differed significantly between the sampled habitats (repeated measures ANOVA, $F_{2}=89.7$, $p<0.0001)$. Bulk sea-ice bacteria increased in numbers slightly a week after ice formation, then decreasing until the last week of ice winter. During winter, abundances in under-ice water were similar to those observed in the water column. After ice melt, bacterial abundance in the water column increased rapidly until the end of sampling period.

Total thymidine incorporation (TTI) rates, a proxy for bacterial cell production, declined steeply compared to bacterial abundance during autumn (Fig. 5, panel b). The minimum productive period in the water column was observed from mid-November to mid-January, with the total thymidine incorporation on average $0.5 \mathrm{pmol}^{-1} \mathrm{~h}^{-1}$. The highest bacterial production rates were observed in the under-ice water, with the production peak of 6.42 TTI pmol $\mathrm{l}^{-1} \mathrm{~h}^{-1}$ on January 21 . Thymidine incorporation rates in ice increased from the initial value of 0.51 after ice formation to $0.68 \mathrm{pmol}^{-1} \mathrm{~h}^{-1}$ end of February, and later peaking at $1.94 \mathrm{pmol}^{-1} \mathrm{~h}^{-1}$ in late March. Over the whole study period, cell-specific production rates were the highest in under-ice water (Fig. 5, panel c), yet the maximum specific productivity was measured from ice 2 weeks before ice melt. While bacterial abundance declined through the study period, cell-specific production had an opposite evolution, with increasing bacterial activity throughout the season.

\section{Seasonal changes in VLP abundance}

Abundance of virus-like particles in the water column increased from $7 \times 10^{6} \mathrm{ml}^{-1}$ in October to $1.4 \times 10^{7} \mathrm{ml}^{-1}$ in December, rapidly decreasing to $5 \times 10^{6} \mathrm{ml}^{-1}$ prior to ice formation in January (Fig. 6). Most notable temporal variation was observed in the under-ice water where the VLP abundances were 2-6 times higher than in the water column 
Fig. 3 Water column, under-ice water and bulk ice temperature and salinity in Tvärminne, Gulf of Finland $\left(59^{\circ} 51.250^{\prime} \mathrm{N}, 23^{\circ}\right.$ $\left.15.815^{\prime} \mathrm{E}\right)$. The timeline from the beginning of January to mid-April represents the icecovered season
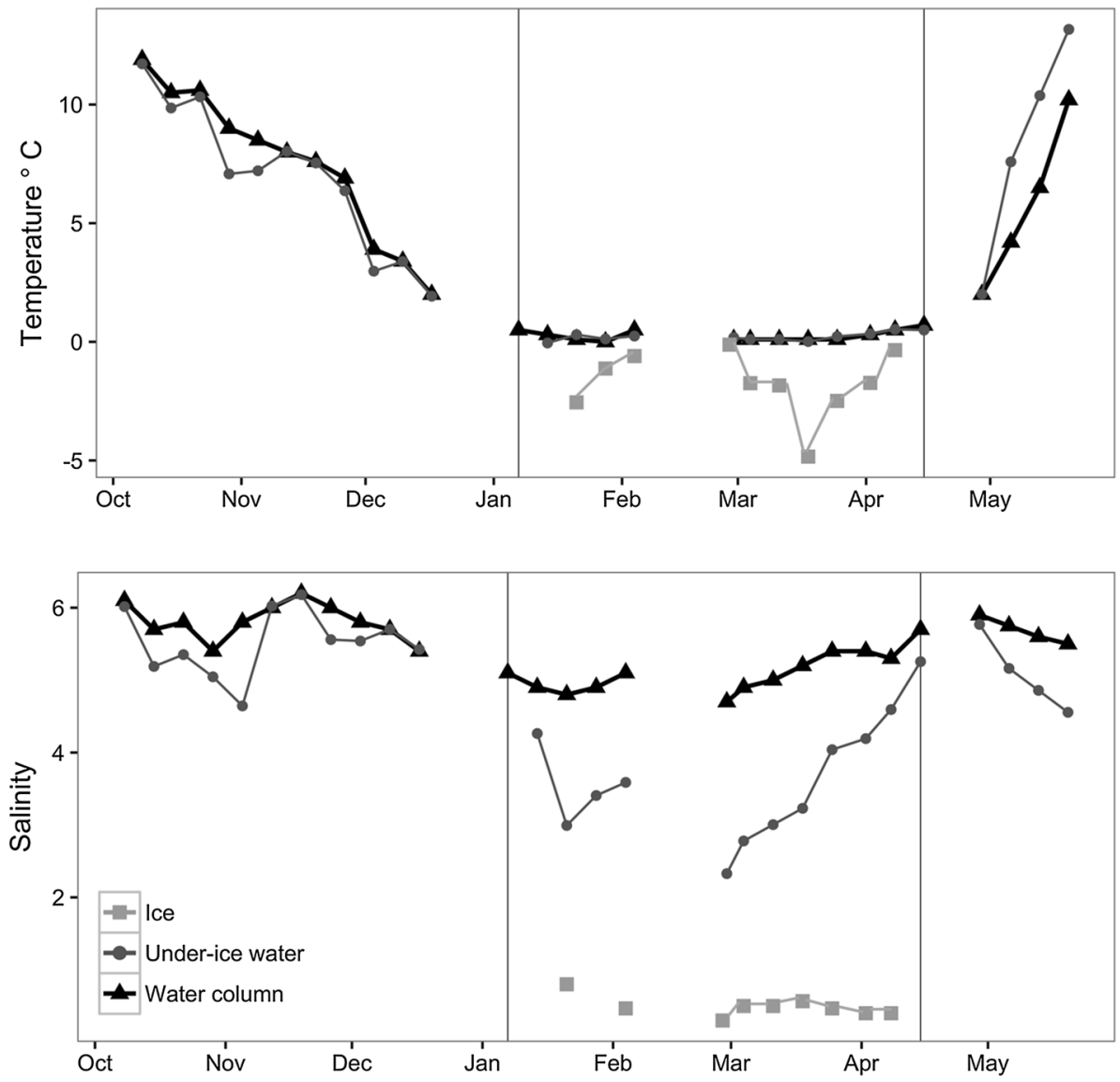

near the end of the ice-covered season. Abundances were significantly different in all sampled habitats (repeated measures ANOVA, $\left.F_{2}=31.42, p<0.0001\right)$. In ice, a clear decline was observed throughout the ice-covered period.

\section{Seasonal changes in nanoflagellate abundance}

Nanoflagellate abundance was the highest in October and decreased abruptly in November (Fig. 7). Maximum abundance during the study period was observed in October with nanoflagellate abundance reaching 12,500 cells $\mathrm{ml}^{-1}$. During winter, cell abundances were 0-2500 cells $\mathrm{ml}^{-1}$. Abundances in sea ice increased throughout the ice-covered period, and the maximum abundance of 7500 nanoflagellate cells $\mathrm{ml}^{-1}$ was observed in April before melting of the sea ice. The highest vernal cell counts were found in sea ice and the under-ice water only days before ice melted. A more detailed description of the nanoflagellate succession is given in Enberg et al. (2018) (site B), where the algal biomass during the ice-covered period was dominated by small flagellates.

\section{Relation of temporal abundance patterns to environmental conditions}

Water temperature correlated positively with bacteria and VLP abundance, (Table 1) whereas in ice no significant correlation was observed between organisms and the ice temperature (Table 2). Similarly, the VAR(1) model results (Table 3) and Granger causality test show that water temperature was found to Granger-cause bacterial abundance $\left(F_{23,-1}=5.9253, p=0.0235\right)$. With the exception of VLP abundance correlated negatively with water column salinity ( $r=0.458, n=29, p=0.0243$, Table 1$)$, no other significant correlations were observed between water or ice salinity and abundance of the studied organisms. Bacterial and VLP abundance correlated negatively with ice depth both in the water column and within the ice (Table 2). Bacteria were found negatively correlated with inorganic nutrient concentrations both in the water column and in ice (Tables 1,2).

\section{Microbial community interactions}

Pearson's product-moment correlation suggests strong positive correlation between the seasonally adjusted bacterial abundance and the number of VLPs in the water column 
Fig. 4 Chlorophyll $a$ concentration in the water column, bulk ice and under-ice water in Tvärminne, Gulf of Finland $\left(59^{\circ} 51.250^{\prime} \mathrm{N}, 23^{\circ} 15.815^{\prime} \mathrm{E}\right)$. Error bars represent standard deviations from replicate samples. The timeline from the beginning of January to midApril represents the ice-covered season

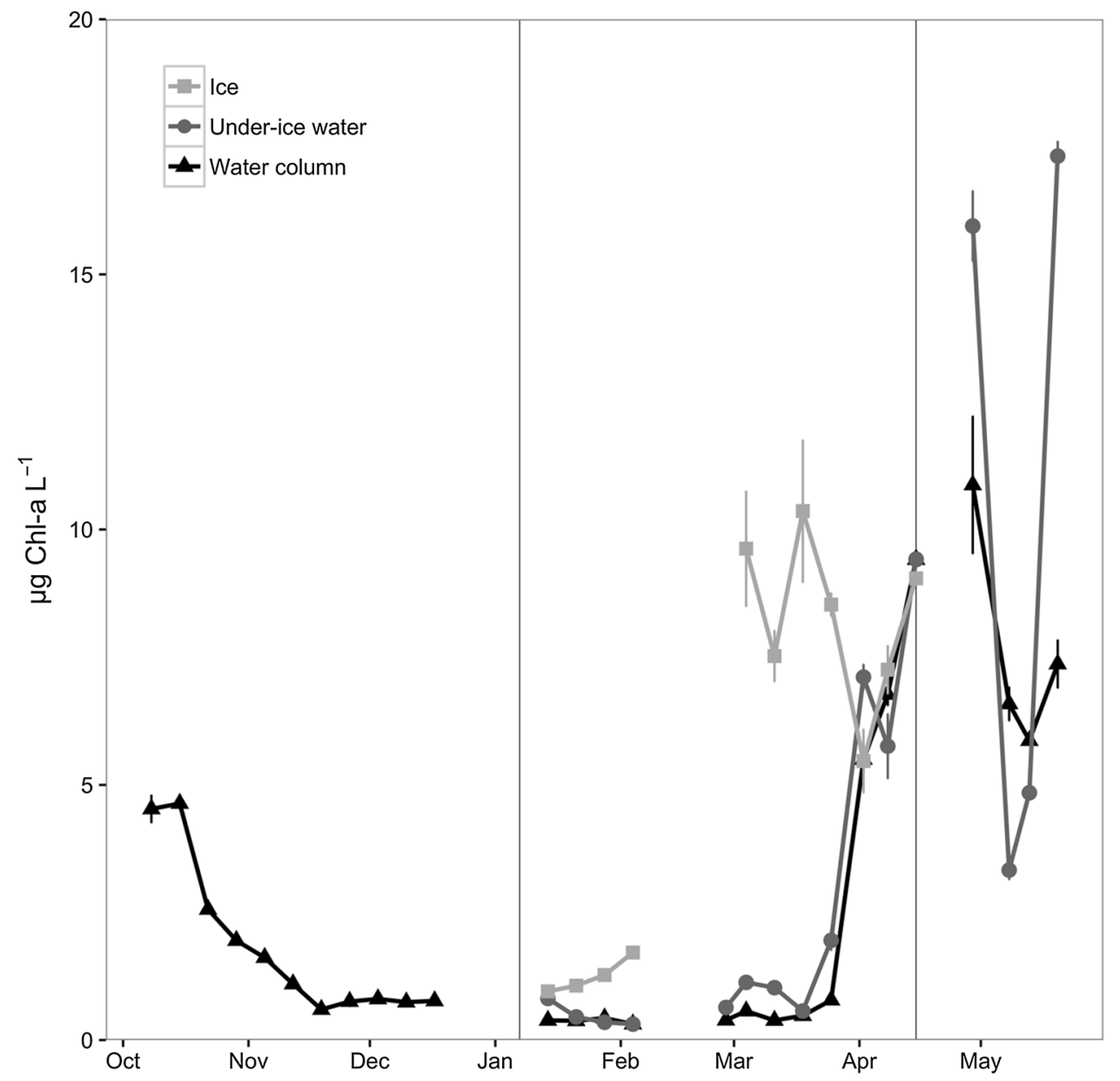

$(r=0.733, n=29, p<0.0001)$ (Table 1). A similar positive correlation $(r=0.756, n=12, p=0.004)$ was observed in ice (Table 2). In ice a significant, albeit relatively low, negative correlation $(r=-0.367, n=12, p=0.007)$ was detected between bacteria and nanoflagellates.

VAR(1) model diagnostics indicate that bacteria Granger-cause VLP, nanoflagellates, and chlorophyll $a$ concentration $\left(F_{3,76}=4.3609, p=0.0069\right)$. This result can be interpreted so that changes in bacterial abundance can be used to predict variation in the abundance of the other organisms. Further, changes in chl $a$ concentration were found to precede changes in nanoflagellate abundance concentration $\left(F_{23,-1}=4.2781, p=0.0506\right)$.

In terms of biological interactions, the statistically significant coefficients of the VAR(1) model and the corresponding tests of Granger causality suggest that bacterial abundance and chlorophyll $a$ concentration at a given time will only be affected by the abundance of the previous sampling of the variable itself, thus the week before in this case (Table 3 ). While VLP lagged abundance was a significant predictor for bacterial abundance, the interaction did not pass the Granger causality test $\left(F_{23,-1}=0.5072, p=0.4838\right)$. The coupled results from the correlation tests and VAR model show that the abundances of organisms are affected by both the short-term interactions, and lagged values from the precedent week.

\section{Discussion}

In this study, we identified distinctive changes in bacterial, VLP, and nanoflagellate abundance in sea ice, the underice water, and the water column from October to May in the northern Baltic Sea. The most prominent differences between the sampled habitats were observed between ice and water column samples, and the sea-ice microbial community had an independent wintertime development from that of the water column. Bacteria, nanoflagellates, and chlorophyll $a$ concentrations in ice decreased or increased more evidently than in the water during the ice-covered period.

During the same seasonal cycle, Enberg et al. (2018) described the succession of the eukaryotic communities 


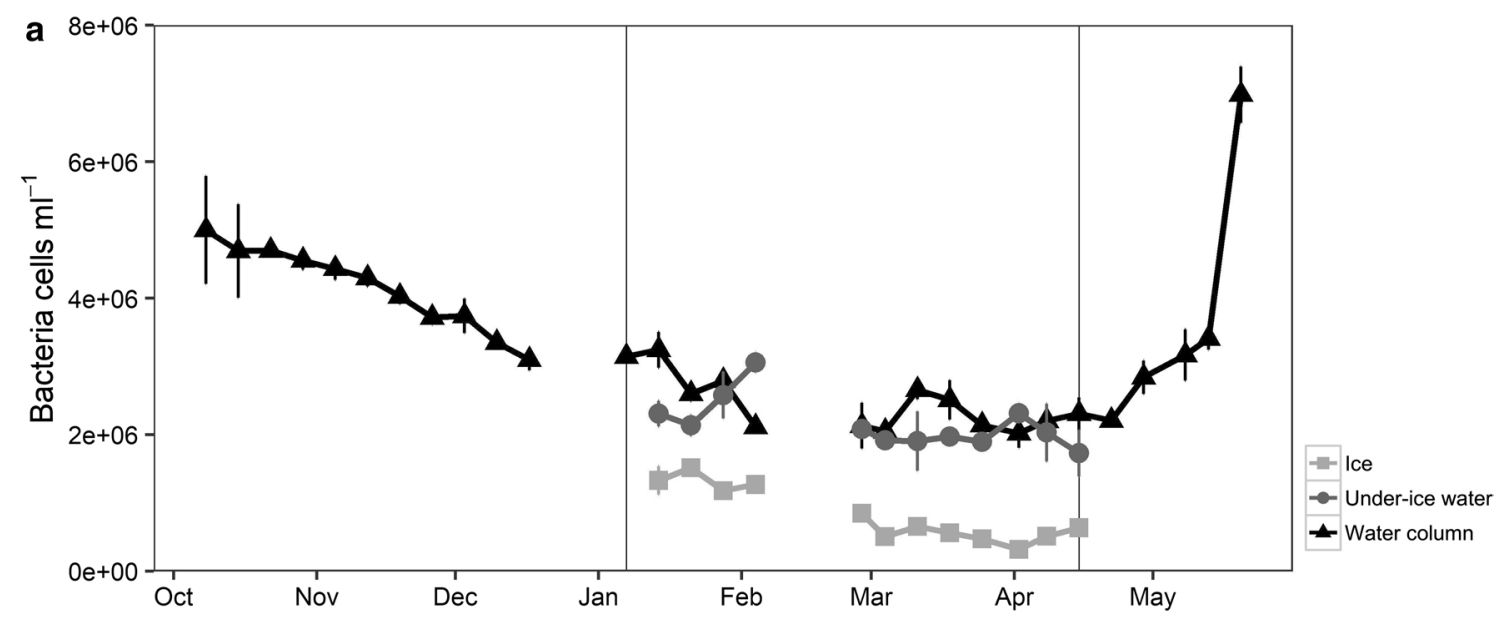

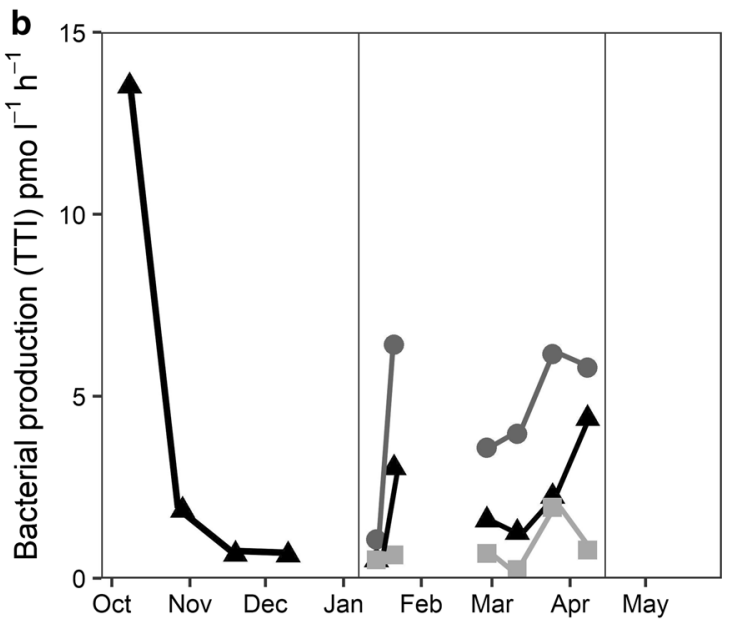

Fig. 5 Bacterial abundance (a), total thymidine incorporation (TTI) (b), and cell-specific bacterial production (c) in the water column, bulk ice and under-ice water in Tvärminne, Gulf of Finland $\left(59^{\circ}\right.$

in ice and water column using microscopy and the $18 \mathrm{~S}$ rRNA gene sequence analysis. Together with Majaneva et al. (2019), they show that different species of flagellates characterize sea ice, under-ice water, and the water column during the sea-ice-covered season. Coupled with results of, not to this study, the distinct communities in the different sea-ice habitats also seem to extend to the abundances of the heterotrophic microbial community.

Abundance patterns of organisms are a result of both environmental factors and biological interactions. Previous time series studies have found bacterial abundance to be connected to both abiotic and biotic factors (Bunse et al. 2018). Here, bacterial increase in the spring coincided with rapidly

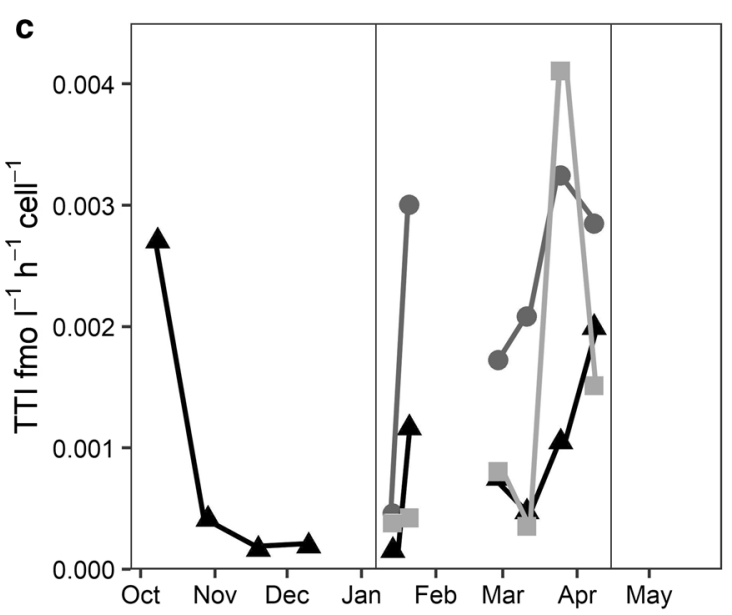

$\left.51.250^{\prime} \mathrm{N}, 23^{\circ} 15.815^{\prime} \mathrm{E}\right)$. Error bars represent standard deviations from replicate samples. The timeline from the beginning of January to mid-April represents the ice-covered season

increasing water temperatures. Our results thus suggest that environmental factors and the history of bacterial abundance affect bacterial abundance more than biological interactions. By examining both the lagged and instantaneous response of organisms, our results show a strong connection between bacterial abundance and temperature. Bacterial growth is also controlled by the production of labile dissolved carbon extracted by algae (Kuparinen et al. 2007), and in our study, the sudden increase in bacterial abundance in the spring seemed to be more connected to the melting of ice than phytoplankton growth. Bacterial community development was thus likely associated with the availability of the algalderived substrate (Eronen-Rasimus et al. 2017). Bacterial 
Fig. 6 VLP abundance in the water column, bulk ice and under-ice water in Tvärminne, Gulf of Finland (59 $51.250^{\prime}$ $\left.\mathrm{N}, 23^{\circ} 15.815^{\prime} \mathrm{E}\right)$. Error bars represent standard deviations from replicate samples. The timeline from the beginning of January to mid-April represents the ice-covered season

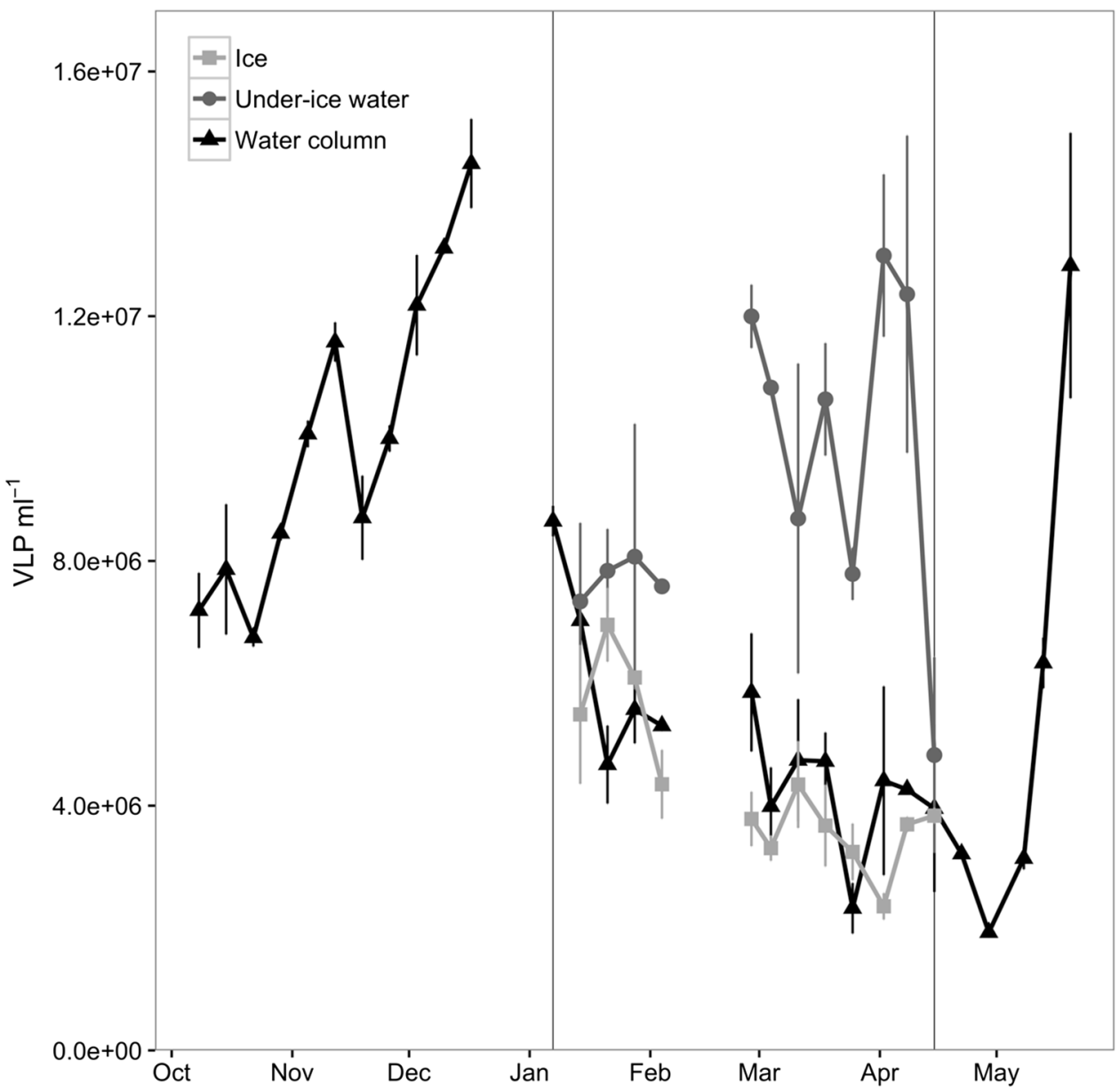

abundance was not directly correlated to chl $a$ concentration, and the carbon incorporated into the algal and nanoflagellate biomass in ice was therefore likely to promote the growth of bacteria through dissolved organic matter transport after ice melted (Kuparinen 1988; Sime-Ngando et al. 1999; Sala et al. 2010). A similar lack of correlation between bacteria and chl $a$ has been shown in other mid-winter studies (Stewart and Fritsen 2004), likely resulting from the relatively low chl $a$ concentrations in ice. This supports previous findings that combined effect of temperature and substrate availability would be most efficient in increasing bacterial abundance (Autio 1998; Kirchman et al. 2005), highlighting the importance of the timing of ice melt for microorganisms.

The bacterial production results of this study show that the dormant period during the winter months is limited to before ice formation, and the heterotrophic production then increases throughout the winter and spring months. Bacterial activity in newly formed sea ice is often suppressed before consolidation of sea ice (Grossmann and Gleitz 1993; Kaartokallio et al. 2008), yet we found that the cell-specific production rates in ice were restored quickly after ice formation. While the low snow cover in our study may have exposed the sea-ice communities to higher solar radiation in the spring, the effects of UVA on bacterial production are limited to surface layers of ice (Piiparinen and Kuosa 2011), and the cell-specific production rates increased throughout the study period. Bacterial production was highest in the under-ice water and within the same ranges in ice than measured by Kaartokallio et al. (2008). While our results show high bacterial abundance during the winter minima, they are in line with earlier coastal studies where bacterial abundances were found to remain relatively low until the melting of the ice (Kuuppo-Leinikki 1990; Heinänen and Kuparinen 1991; Tuomi 1997; Kaartokallio 2004).

The highest nanoflagellate abundances were observed at the end of the growth season when also bacterial abundances 
Fig. 7 Nanoflagellate abundance in the water column, bulk ice and under-ice water in Tvärminne, Gulf of Finland (59 $\left.51.250^{\prime} \mathrm{N}, 23^{\circ} 15.815^{\prime} \mathrm{E}\right)$. The timeline from the beginning of January to mid-April represents the ice-covered season

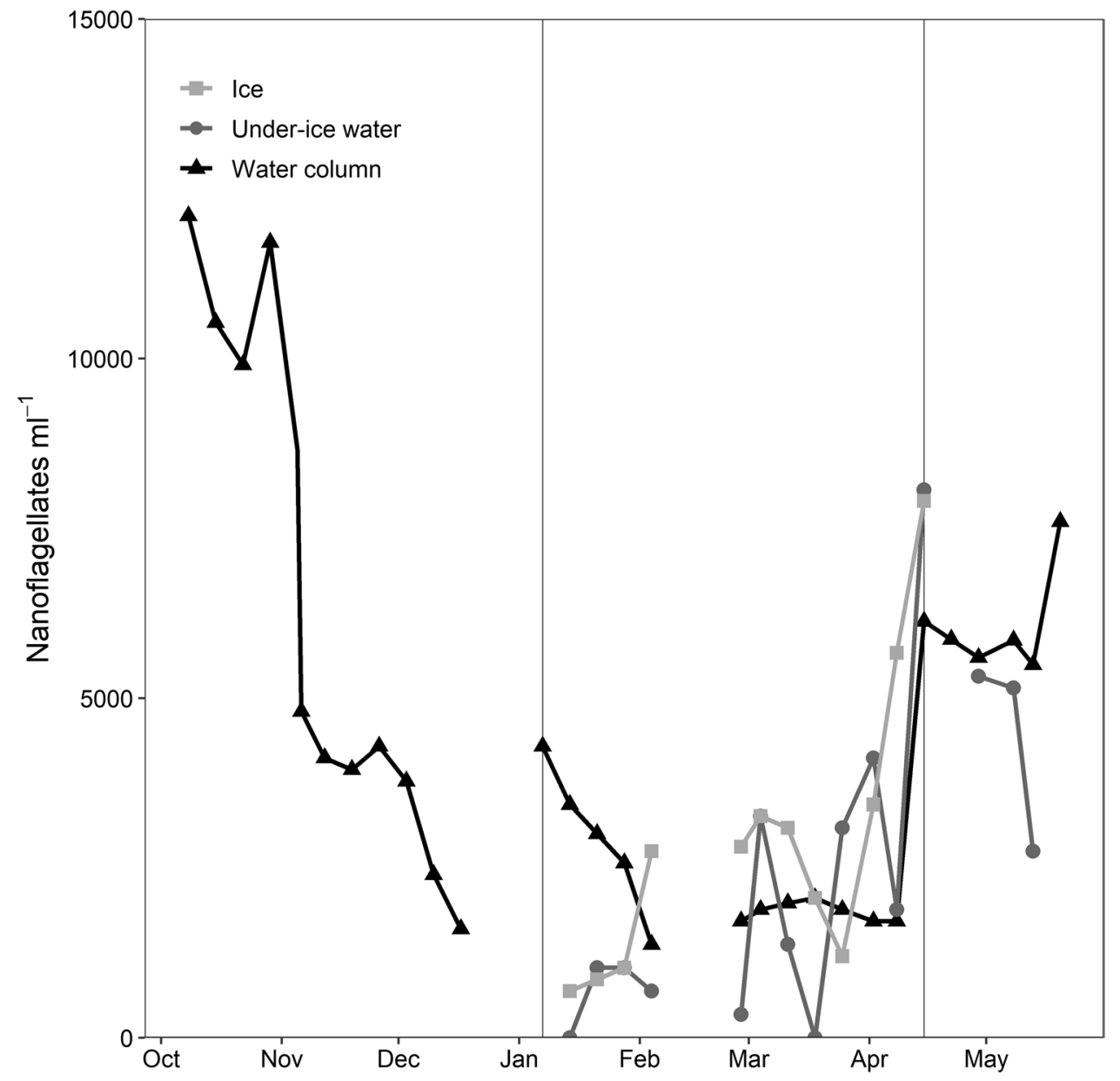

were the highest, potentially providing sufficient resources for nanoflagellate growth (Kuosa and Kivi 1989; Kivi et al. 1993). Although traditionally autotrophic and heterotrophic flagellates are treated separately, even chlorophyll containing nanoflagellates have been observed to consume bacteria (Estep et al. 1986). Mixotrophic behaviour, which combines both autotrophic and heterotrophic modes of energy acquisition, is widely spread among flagellates (Sanders and Gast 2012). Following the eukaryote succession during the same seasonal cycle, Enberg et al. (2018) showed that cryptophytes and haptophytes were some of the most abundant flagellate taxa at the end of the ice-covered period, some of which are known capable of mixotrophy. The autoregressive model supports this finding by indicating that changes in nanoflagellate abundance can be explained by both bacterial abundance and chl $a$ concentration. Both the increasing light intensities and higher bacterial biomass thus likely contributed to the development of the nanoflagellate biomass.
As bacteria are the most abundant hosts of viruses, viral production is often linked to bacterial production and abundance (Steward et al. 1996; Sandaa et al. 2018). In this study, VLP appeared in large quantities in the autumn at the beginning of the cold-water period. This phenomenon may be a result of induction of lysogenic viruses during the temperature decrease or viral control of the bacterial population during this period (Collins and Deming 2011). High virus abundances together with low bacterial abundance and activity have also been detected in newly formed sea ice (Collins and Deming 2011; Luhtanen et al. 2018). VLP abundances showed both great irregular temporal variation and distinctive abundance patterns in the sampled habitats, especially the under-ice water. Weekly averages of total virioplankton can have an annual variation up to one order of magnitude (Li and Dickie 2001), and the virus-to-host cell ratio decreases with microbial cell density (Wigington et al. 2016). The results from the autoregressive model support 
Table 1 Pearson's product-moment correlation coefficient for the water column samples

\begin{tabular}{lllc}
\hline & Bacteria & VLP & Nanoflagellates \\
\hline Bacteria & & 0.733 & 0.196 \\
VLP & & $p<0.0001$ & $p=0.335$ \\
& 0.733 & & -0.005 \\
Nanoflagellates & $p<0.0001$ & & $p=0.9787$ \\
& 0.196 & -0.005 & \\
Chl $a$ & $p=0.335$ & $p=0.9787$ & \\
& 0.363 & 0.061 & 0.072 \\
Water temperature & $p=0.074$ & $p=0.7713$ & $p=0.726$ \\
& 0.857 & 0.512 & 0.325 \\
Salinity & $p<0.0001$ & $p=0.0105$ & $p=0.1125$ \\
& -0.033 & -0.458 & 0.298 \\
Ice depth & $p=0.8755$ & $p=0.0243$ & $p=0.147$ \\
Ammonium & -0.705 & -0.622 & -0.383 \\
& $p<0.0001$ & $p=0.0018$ & $p=0.0013$ \\
Si & 0.218 & 0.376 & 0.155 \\
& $p=0.2376$ & $p=0.037$ & $p=0.404$ \\
Nitrate & -0.602 & -0.094 & -0.431 \\
& $p=0.0003$ & $p=0.6125$ & $p=0.01544$ \\
Phosphate & -0.642 & -0.005 & -0.517 \\
& $p<0.0001$ & $p=0.9755$ & $p=0.0028$ \\
& -0.395 & -0.230 & -0.550 \\
& $p=0.0280$ & $p=0.1048$ & $p=0.0013$ \\
\hline & & &
\end{tabular}

Table 2 Pearson's product-moment correlation coefficient for the bulk ice samples

\begin{tabular}{|c|c|c|c|}
\hline & Bacteria & VLP & Nanoflagellates \\
\hline Bacteria & & $\begin{array}{l}0.756 \\
p=0.0045\end{array}$ & $\begin{array}{l}-0.367 \\
p=0.1198\end{array}$ \\
\hline VLP & $\begin{array}{l}0.756 \\
p=0.0045\end{array}$ & & $\begin{array}{l}0.619 \\
p=0.032\end{array}$ \\
\hline Nanoflagellates & $\begin{array}{l}-0.367 \\
p=0.1198\end{array}$ & $\begin{array}{l}0.619 \\
p=0.032\end{array}$ & \\
\hline Ice salinity & $\begin{array}{l}0.421 \\
p=0.3458\end{array}$ & $\begin{array}{l}0.332 \\
p=0.466\end{array}$ & $\begin{array}{l}0.473 \\
p=0.467\end{array}$ \\
\hline Ice temperature & $\begin{array}{l}-0.391 \\
p=0.3379\end{array}$ & $\begin{array}{l}-0.286 \\
p=0.4911\end{array}$ & $\begin{array}{l}-0.287 \\
p=0.2769\end{array}$ \\
\hline Chl $a$ & $\begin{array}{l}-0.562 \\
p=0.0567\end{array}$ & $\begin{array}{l}-0.146 \\
p=0.6489\end{array}$ & $\begin{array}{l}0.165 \\
p=0.6086\end{array}$ \\
\hline Ice depth & $\begin{array}{l}-0.849 \\
p<0.0001\end{array}$ & $\begin{array}{l}-0.480 \\
p=0.0440\end{array}$ & $\begin{array}{l}0.317 \\
p=0.2005\end{array}$ \\
\hline Snow cover depth & $\begin{array}{l}0.521 \\
p=0.1851\end{array}$ & $\begin{array}{l}0.555 \\
p=0.1535\end{array}$ & $\begin{array}{l}0.436 \\
p=0.2802\end{array}$ \\
\hline Ammonium & $\begin{array}{l}-0.054 \\
p=0.8321\end{array}$ & $\begin{array}{l}0.329 \\
p=0.3549\end{array}$ & $\begin{array}{l}0.620 \\
p=0.0060\end{array}$ \\
\hline $\mathrm{Si}$ & $\begin{array}{l}0.364 \\
p=0.1372\end{array}$ & $\begin{array}{l}0.220 \\
p=0.3786\end{array}$ & $\begin{array}{l}-0.044 \\
p=0.8634\end{array}$ \\
\hline Nitrate & $\begin{array}{l}0.082 \\
p=0.1824\end{array}$ & $\begin{array}{l}-0.212 \\
p=0.777\end{array}$ & $\begin{array}{l}0.022 \\
p=0.9091\end{array}$ \\
\hline Phosphate & $\begin{array}{l}0.662 \\
p=0.0027\end{array}$ & $\begin{array}{l}0.500 \\
p=0.03597\end{array}$ & $\begin{array}{l}-0.370 \\
p=0.1315\end{array}$ \\
\hline
\end{tabular}

this by showing that VLP and bacterial abundance are interconnected, and the changes in bacterial abundance (either increasing or decreasing) mediate VLP abundance.

While there is considerable natural variation in viral abundance, the observed temporal changes in VLP abundances in this study may in part be due to methodological limitations. We hypothesize that the high VLP abundances in the under-ice water during the winter-spring transition are a result of induction of lysogenic viruses in warming ice, and particle flushing from the enlarging brine channels. Although virioplankton abundances are typically higher in the surface layers of the ocean (Liang et al. 2014), we cannot exclude that the observed particles may be other organic particles with decayed nucleic acid fragments. However, compared to the water column and the brine channels in sea ice, the under-ice water is a more dynamic environment as it is exposed to convection at the ice water interface (Hudier et al. 1995). A shorter sampling interval would therefore be adequate to characterize the temporal viral dynamics (Sandaa et al. 2018) and interactions between other organisms in the marine environment. Furthermore, unraveling the complex interactions between viruses, their hosts, and environmental factors would require significantly longer time series to increase the number of data points.

Bacteria have a key role in the microbial food web, and we found fluctuations in bacterial abundance to precede changes in the abundances of VLP and nanoflagellates. As interactions between organisms may change within a seasonal cycle, assigning only unidirectional interactions and assessing their significance bears limited importance to understanding community dynamics within seasonal changes. Here, the use of an autoregressive model in addition to correlation analysis provided a more complete overview on the interactions between organisms. However, changes of biota in the ice and in the water column coupled with drastic variations in temperature and biotic interactions make the system quite complicated, and the independent effects of biological interaction cannot be fully depicted by the results of this study.

While our study system is notably lower salinity than many other sub-Arctic marine areas, the changes observed here throughout the low-light season may reflect future conditions in other coastal high latitude systems (Carmack et al. 2016). Because of the importance of ice cover for timing of biomass peaks in the microbial community, changing ice conditions are likely to affect microbial community phenologies and interactions. Our results provide first insights into the temporal dynamics of bacteria and viruses during the whole cold-water season, and demonstrate that changes in the environmental conditions are likely to affect bacterial dynamics and alter trophic interactions. 
Table 3 Model coefficients and statistics for the best fitting restricted $\operatorname{VAR}(1)$ models in the water column

\begin{tabular}{|c|c|c|c|c|c|}
\hline Dependent variable & & Coefficient estimate & Standard error & $t$-value & $p$ value \\
\hline \multirow[t]{6}{*}{ Bacteria } & Bacteria $_{t-1}$ & 0.7393 & 0.3543 & 2.087 & 0.0523 \\
\hline & $\mathrm{VLP}_{t-1}$ & 0.3663 & 0.1184 & 3.093 & 0.0066 \\
\hline & $\mathrm{NF}_{t-1}$ & 0.0250 & 0.1022 & -0.245 & 0.8097 \\
\hline & Chl $a_{t-1}$ & -0.1239 & 0.1261 & -0.983 & 0.3395 \\
\hline & Temperature $_{t-1}$ & 1.3121 & 0.2628 & 4.993 & 0.0001 \\
\hline & Salinity $_{t-1}$ & -0.3822 & 0.1236 & -3.092 & 0.0066 \\
\hline \multirow[t]{6}{*}{ VLP } & Bacteria $_{t-1}$ & 0.3490 & 0.6159 & 0.567 & 0.5783 \\
\hline & $\mathrm{VLP}_{t-1}$ & 0.7721 & 0.2059 & 3.750 & 0.0016 \\
\hline & $\mathrm{NF}_{t-1}$ & 0.1681 & 0.1777 & 0.946 & 0.3574 \\
\hline & Chl $a$ & 0.4455 & 0.2192 & -2.032 & 0.0581 \\
\hline & Temperature $_{t-1}$ & 0.5211 & 0.4568 & 1.141 & 0.2698 \\
\hline & Salinity $_{t-1}$ & 0.1088 & 0.2149 & 0.506 & 0.6191 \\
\hline \multirow[t]{6}{*}{ Nanoflagellates } & Bacteria $_{t-1}$ & 0.4160 & 0.7462 & 0.557 & 0.5845 \\
\hline & $\mathrm{VLP}_{t-1}$ & 0.0422 & 0.2495 & 0.169 & 0.8676 \\
\hline & $\mathrm{NF}_{\mathrm{t}-1}$ & -0.3335 & 0.2153 & -1.549 & 0.1397 \\
\hline & Chl $a_{t-1}$ & 0.5615 & 0.2656 & 2.114 & 0.0496 \\
\hline & Temperature $_{t-1}$ & 0.7567 & 0.5535 & 1.367 & 0.1894 \\
\hline & Salinity $_{t-1}$ & -0.3818 & 0.2604 & -1.466 & 0.1608 \\
\hline \multirow[t]{6}{*}{ Chl $a$} & Bacteria $_{t-1}$ & -0.8819 & 0.4809 & -1.834 & 0.0842 \\
\hline & $\mathrm{VLP}_{t-1}$ & 0.0478 & 0.1608 & 0.298 & 0.7697 \\
\hline & $\mathrm{NF}_{t-1}$ & 0.1085 & 0.1387 & 0.782 & 0.4449 \\
\hline & Chl $a_{t-1}$ & 0.6806 & 0.1712 & 3.977 & 0.0010 \\
\hline & Temperature $_{t-1}$ & 0.5432 & 0.3567 & 1.523 & 0.1461 \\
\hline & Salinity $_{t-1}$ & 0.0456 & 0.1678 & 0.272 & 0.7886 \\
\hline
\end{tabular}

Acknowledgements Open access funding provided by University of Helsinki including Helsinki University Central Hospital. This work was supported by The Walter and Andrée de Nottbeck Foundation and Maa- ja vesitekniikan tuki ry. The field and laboratory work were made possible by the facilities at Tvärminne Zoological Station, the Faculty of Biological and Environmental Sciences (University of Helsinki), and Marine Research Centre (Finnish Environment Institute). Göran Lundberg, Veijo Kinnunen and Dr. Joanna Norkko are acknowledged for their help in the fieldwork and Dr. Harri Kuosa for his help with the flagellate enumeration. We are grateful to Dr. Markus Majaneva, Samy Clinchard, and the three reviewers for all their comments that greatly improved this manuscript.

\section{Compliance with ethical standards}

Conflicts of interest All authors declare that they have no conflict of interest.

Open Access This article is licensed under a Creative Commons Attribution 4.0 International License, which permits use, sharing, adaptation, distribution and reproduction in any medium or format, as long as you give appropriate credit to the original author(s) and the source, provide a link to the Creative Commons licence, and indicate if changes were made. The images or other third party material in this article are included in the article's Creative Commons licence, unless indicated otherwise in a credit line to the material. If material is not included in the article's Creative Commons licence and your intended use is not permitted by statutory regulation or exceeds the permitted use, you will need to obtain permission directly from the copyright holder. To view a copy of this licence, visit http://creativecommons.org/licenses/by/4.0/.

\section{References}

Andersson A, Hajdu S, Haecky P, Kuparinen J, Wikner J (1996) Succession and growth limitation of phytoplankton in the Gulf of Bothnia (Baltic Sea). Mar Biol 126:791-801

Arrigo KR (2014) Sea ice ecosystems. Annu Rev Mar Sci 6:439-467

Autio R (1998) Response of seasonally cold-water bacterioplankton to temperature and substrate treatments. Estuar Coast Shelf Sci 46:465-474

Azam F, Fenchel T, Field JG, Grat JS, Meyer-Reil LA, Thingstad F (1983) The ecological role of water-column microbes in the sea. Mar Ecol Prog Ser 10:257-263

Boetius A, Anesio AM, Deming JW, Mikucki J, Rapp J (2015) Microbial ecology of the cryosphere: sea ice and glacial habitats. Nat Rev Microbiol 13:677

Borcard D, Gillet F, Legendre P (2018) Numerical ecology with R. Springer, Berlin

Brussaard CP, Payet JP, Winter C, Weinbauer MG (2010) Quantification of aquatic viruses by flow cytometry. Man Aquat Viral Ecol 11:102-107

Bunse C, Israelsson S, Baltar F et al (2018) High frequency multiyear variability in Baltic Sea microbial plankton stocks and activities. Front Microbiol 9:3296

Carmack EC, Yamamoto-Kawai M, Haine TW et al (2016) Freshwater and its role in the Arctic Marine System: sources, disposition, storage, export, and physical and biogeochemical consequences in the Arctic and global oceans. J Geophys Res Biogeosci 121:675-717 
Caron DA, Gast RJ, Garneau M-È (2017) Sea ice as a habitat for micrograzers. In: Thomas DN (ed) Sea ice. Wiley, Chichester, pp 370-393

Chatfield C (2016) The analysis of time series: an introduction. CRC Press, Boca Raton

Collins RE, Deming JW (2011) Abundant dissolved genetic material in Arctic sea ice Part II: viral dynamics during autumn freezeup. Polar Biol 34:1831-1841

Daufresne M, Lengfellner K, Sommer U (2009) Global warming benefits the small in aquatic ecosystems. Proc Natl Acad Sci 106:12788-12793

Ejsmond MJ, Blackburn N, Fridolfsson E et al (2019) Modeling vitamin B 1 transfer to consumers in the aquatic food web. Sci Rep 9:1-11

Enberg S, Majaneva M, Autio R, Blomster J, Rintala J-M (2018) Phases of microalgal succession in sea ice and the water column in the Baltic Sea from autumn to spring. Mar Ecol Prog Ser 599:19-34

Eronen-Rasimus E, Lyra C, Rintala J-M, Jurgens K, Ikonen V, Kaartokallio $\mathrm{H}$ (2015) Ice formation and growth shape bacterial community structure in Baltic Sea drift ice. FEMS Microbiol Ecol 91:1-13

Eronen-Rasimus E, Luhtanen A-M, Rintala J-M, Delille B, Dieckmann G, Karkman A, Tison J-L (2017) An active bacterial community linked to high chl-a concentrations in Antarctic winter-pack ice and evidence for the development of an anaerobic sea-ice bacterial community. ISME J 11:2345-2355

Estep KW, Davis PG, Keller MD, Sieburth JM (1986) How important are oceanic algal nanoflagellates in bacterivory? Limnol Oceanogr 31:646-650

Faust K, Lahti L, Gonze D, De Vos W, Raes J (2015) Metagenomics meets time series analysis: unraveling microbial community dynamics. Curr Opin Microbiol 25:56-66

Fuhrman JA, Azam F (1980) Bacterioplankton secondary production estimates for coastal waters of British Columbia, Antarctica, and California. Appl Environ Microbiol 39:1085-1095

Fuhrman JA, Azam F (1982) Thymidine incorporation as a measure of heterotrophic bacterioplankton production in marine surface waters: evaluation and field results. Mar Biol 66:109-120

Gradinger R, Ikävalko J (1998) Organism incorporation into newly forming Arctic sea ice in the Greenland Sea. J Plankton Res 20:871-886

Granger CW (1969) Investigating causal relations by econometric models and cross-spectral methods. Econom J Econom Soc $37: 424-438$

Grossmann S, Gleitz M (1993) Microbial responses to experimental sea-ice formation: implications for the establishment of Antarctic sea-ice communities. J Exp Mar Biol Ecol 173:273-289

Haas LW (1982) Improved epifluorescence microscopic technique for observing planktonic micro-organisms. Ann Inst Ocean Paris 58:261-266

Hansen HP, Koroleff F (1999) Determination of nutrients. Methods Seawater Anal. https://doi.org/10.1002/9783527613984.ch10

Hassett BT, Gradinger R (2016) Chytrids dominate arctic marine fungal communities. Environ Microbiol 18:2001-2009

Hassett BT, Borrego EJ, Vonnahme TR, Peng X, Jones EB, Heuze C (2019) Arctic marine fungi: biomass, functional genes, and putative ecological roles. ISME J 13:1484-1496

Heinänen A, Kuparinen J (1991) Horizontal variation of bacterioplankton in the Baltic Sea. Appl Environ Microbiol 57:3150-3155

HELCOM, Commission BMEP (1988) Guidelines for the Baltic monitoring programme for the third stage. Baltic Marine Environment Protection Commission

Hudier E-J, Ingram RG, Shirasawa K (1995) Upward flushing of sea water through first year ice. Atmos Ocean 33:569-580
Hunt GL Jr, Drinkwater KF, Arrigo K et al (2016) Advection in polar and sub-polar environments: impacts on high latitude marine ecosystems. Prog Oceanogr 149:40-81

Iversen KR, Seuthe L (2011) Seasonal microbial processes in a highlatitude fjord (Kongsfjorden, Svalbard): I. heterotrophic bacteria, picoplankton and nanoflagellates. Polar Biol 34:731-749

Jylhä K, Fronzek S, Tuomenvirta H, Carter T, Ruosteenoja K (2008) Changes in frost, snow and Baltic sea ice by the end of the twentyfirst century based on climate model projections for Europe. Clim Change 86:441-462

Kaartokallio H (2004) Food web components, and physical and chemical properties of Baltic Sea ice. Mar Ecol Prog Ser 273:49-63

Kaartokallio H, Tuomainen J, Kuosa H, Kuparinen J, Martikainen P, Servomaa K (2008) Succession of sea-ice bacterial communities in the Baltic Sea fast ice. Polar Biol 31:783-793

Kahru M, Elmgren R, Savchuk OP (2016) Changing seasonality of the Baltic Sea. Biogeosci Discuss 13:1009-1018

Karner MB, DeLong EF, Karl DM (2001) Archaeal dominance in the mesopelagic zone of the Pacific Ocean. Nature 409:507-510

Kirchman DL, Malmstrom RR, Cottrell MT (2005) Control of bacterial growth by temperature and organic matter in the Western Arctic. Deep Sea Res Part II Top Stud Oceanogr 52:3386-3395

Kivi K, Kaitala S, Kuosa H et al (1993) Nutrient limitation and grazing control of the Baltic plankton community during annual succession. Limnol Oceanogr 38:893-905

Krembs C, Gradinger R, Spindler M (2000) Implications of brine channel geometry and surface area for the interaction of sympagic organisms in Arctic sea ice. J Exp Mar Biol Ecol 243:55-80

Kuosa H (1991) Picoplanktonic algae in the northern Baltic Sea: seasonal dynamis and flagellate grazing. Mar Ecol Prog Ser 73:269-276

Kuosa H, Kivi K (1989) Bacteria and heterotrophic flagellates in the pelagic carbon cycle in the northern Baltic Sea. Mar Ecol Prog Ser 53:93-100

Kuparinen J (1988) Development of bacterioplankton during winter and early spring at the entrance to the Gulf of Finland, Baltic Sea: with 4 figures and 5 tables in the text. Int Ver Für Theor Angew Limnol Verhandlungen 23:1869-1878

Kuparinen J, Kuosa H, Andersson A et al (2007) Role of sea-ice biota in nutrient and organic material cycles in the northern Baltic Sea. AMBIO J Hum Environ 36:149-154

Kuuppo-Leinikki P (1990) Protozoan grazing on planktonic bacteria and its impact on bacterial population. Mar Ecol Prog Ser 63:227-238

Leu E, Mundy CJ, Assmy P et al (2015) Arctic spring awakeningsteering principles behind the phenology of vernal ice algal blooms. Prog Oceanogr 139:151-170

Li WKW, Dickie PM (2001) Monitoring phytoplankton, bacterioplankton, and virioplankton in a coastal inlet (Bedford Basin) by flow cytometry. Cytometry A 44:236-246

Liang Y, Li L, Luo T, Zhang Y, Zhang R, Jiao N (2014) Horizontal and vertical distribution of marine virioplankton: a basin scale investigation based on a global cruise. PLoS ONE 9:e111634

Lizotte MP (2003) The microbiology of sea ice. Sea Ice Introd Phys Chem Biol Geol. https://doi.org/10.1002/9780470757 161\#page $=198$

Luhtanen A-M, Eronen-Rasimus E, Oksanen HM et al (2018) The first known virus isolates from Antarctic sea ice have complex infection patterns. FEMS Microbiol Ecol 94:fiy028

Lund JWG, Kipling C, Le Cren ED (1958) The inverted microscope method of estimating algal numbers and the statistical basis of estimations by counting. Hydrobiologia 11:143-170

Majaneva M, Autio R, Huttunen M, Kuosa H, Kuparinen J (2009) Phytoplankton monitoring: the effect of sampling methods used 
during different stratification and bloom conditions in the Baltic Sea. Boreal Environ Res 14:313-322

Majaneva M, Enberg S, Autio R, Blomster J, Rintala J-M (2019) Mamiellophyceae shift in seasonal predominance in the Baltic Sea. Aquat Microb Ecol 83:181-187

Marie D, Brussaard C, Partensky F et al (1999) Flow cytometric analysis of phytoplankton, bacteria and viruses. Curr Protoc Cytom 11:1-15

Marquardt M, Vader A, Stübner EI et al (2016) Strong seasonality of marine microbial eukaryotes in a high-arctic fjord (Isfjorden, in West Spitsbergen, Norway). Appl Environ Microbiol 82:1868-1880

Mary I, Cummings DG, Biegala IC et al (2006) Seasonal dynamics of bacterioplankton community structure at a coastal station in the western English Channel. Aquat Microb Ecol 42:119-126

Mock T, Thomas DN (2005) Recent advances in sea-ice microbiology. Environ Microbiol 7:605-619

Mock T, Meiners KM, Giesenhagen HC (1997) Bacteria in sea ice and underlying brackish water at $54^{\circ} 26^{\prime} 50^{\prime \prime} \mathrm{N}$ (Baltic Sea, Kiel Bight). Mar Ecol Prog Ser 158:23-40

Moreau S, Ferreyra GA, Mercier B et al (2010) Variability of the microbial community in the western Antarctic Peninsula from late fall to spring during a low ice cover year. Polar Biol 33:1599-1614

Petrich C, Eicken H (2010) Growth, structure and properties of sea ice. Sea Ice 2:23-77

Pfaff B (2008a) Analysis of integrated and cointegrated time series with R. Springer, Berlin

Pfaff B (2008b) VAR, SVAR and SVEC models: implementation within R package vars. J Stat Softw 27:1-32

Piiparinen J, Kuosa H (2011) Impact of UVA radiation on algae and bacteria in Baltic Sea ice. Aquat Microb Ecol 63:75-87

Pinhassi J, Hagström A (2000) Seasonal succession in marine bacterioplankton. Aquat Microb Ecol 21:245-256

Proctor LM, Fuhrman JA (1990) Viral mortality of marine bacteria and cyanobacteria. Nature 343:60

R Core Team (2019) R: a language and environment for statistical computing. R Foundation for Statistical Computing, Vienna, Austria. https://www.R-project.org/

Rintala J-M, Piiparinen J, Blomster J, Majaneva M, Muller S, Uusikivi J, Autio R (2014) Fast direct melting of brackish sea-ice samples results in biologically more accurate results than slow buffered melting. Polar Biol 37:1811-1822

Rózańska M, Gosselin M, Poulin M et al (2009) Influence of environmental factors on the development of bottom ice protist communities during the winter-spring transition. Mar Ecol Prog Ser $386: 43-59$

Sakshaug E (2004) Primary and secondary production in the Arctic Seas. In: The organic carbon cycle in the Arctic Ocean. Springer, Berlin, pp 57-81

Sala MM, Arrieta JM, Boras JA, Duarte C, Vaque D (2010) The impact of ice melting on bacterioplankton in the Arctic Ocean. Polar Biol 33:1683-1694

Sandaa R-A, Storesund EJ, Olesin E et al (2018) Seasonality drives microbial community structure, shaping both eukaryotic and prokaryotic host-viral relationships in an Arctic marine ecosystem. Viruses 10:715

Sanders RW, Gast RJ (2012) Bacterivory by phototrophic picoplankton and nanoplankton in Arctic waters. FEMS Microbiol Ecol $82: 242-253$

Schauer M, Balagué V, Pedrós-Alió C, Massana R (2003) Seasonal changes in the taxonomic composition of bacterioplankton in a coastal oligotrophic system. Aquat Microb Ecol 31:163-174

Sime-Ngando T, Demers S, Juniper SK (1999) Protozoan bacterivory in the ice and the water column of a cold temperate lagoon. Microb Ecol 37:95-106
Steward GF, Smith DC, Azam F (1996) Abundance and production of bacteria and viruses in the Bering and Chukchi Seas. Mar Ecol Prog Ser 131:287-300

Stewart FJ, Fritsen CH (2004) Bacteria-algae relationships in Antarctic sea ice. Antarct Sci 16:143-156

Suttle CA (2005) Viruses in the sea. Nature 437:356-361

Sydeman WJ, Bograd SJ (2009) Marine ecosystems, climate and phenology: introduction. Mar Ecol Prog Ser 393:185-188

Tedesco L, Vichi M, Scoccimarro E (2019) Sea-ice algal phenology in a warmer Arctic. Sci Adv 5:eaav4830

Thomas DN, Kaartokallio H, Tedesco L et al (2017) Life associated with Baltic Sea ice. In: Biological oceanography of the Baltic Sea. Springer, Berlin, pp 333-357

Tophøj J, Wollenberg RD, Sondergaard TE, Eriksen NT (2018) Feeding and growth of the marine heterotrophic nanoflagellates, Procryptobia sorokini and Paraphysomonas imperforata on a bacterium, Pseudoalteromonas sp. with an inducible defence against grazing. PLoS ONE 13:e0195935

Tsai AY, Gong G-C, Hung J (2013) Seasonal variations of virus-and nanoflagellate-mediated mortality of heterotrophic bacteria in the coastal ecosystem of subtropical western Pacific. Biogeosciences 10:3055-3065

Tsai A-Y, Gong G-C, Chao CF (2016) Contribution of viral lysis and nanoflagellate grazing to bacterial mortality at surface waters and deeper depths in the coastal ecosystem of subtropical Western Pacific. Estuaries Coasts 39:1357-1366

Tuomi P (1997) Bacterial carbon production in the northern Baltic: a comparison of thymidine incorporation and FDC based methods. Mar Ecol Prog Ser 153:59-66

Umani SF, Malisana E, Focaracci F et al (2010) Disentangling the effect of viruses and nanoflagellates on prokaryotes in bathypelagic waters of the Mediterranean Sea. Mar Ecol Prog Ser 418:73-85

Vihma T, Haapala J (2009) Geophysics of sea ice in the Baltic Sea: a review. Prog Oceanogr 80:129-148

Weissenberger J, Dieckmann G, Gradinger R, Spindler M (1992) Sea ice: a cast technique to examine and analyze brine pockets and channel structure. Limnol Oceanogr 37:179-183

Whitman WB, Coleman DC, Wiebe WJ (1998) Prokaryotes: the unseen majority. Proc Natl Acad Sci 95:6578-6583

Wigington CH, Sonderegger D, Brussaard CP et al (2016) Re-examination of the relationship between marine virus and microbial cell abundances. Nat Microbiol 1:15024

Wilhelm SW, Suttle CA (1999) Viruses and nutrient cycles in the sea: viruses play critical roles in the structure and function of aquatic food webs. Bioscience 49:781-788

Yakubov S, Wallhead P, Protsenko E et al (2019) A 1-dimensional sympagic-pelagic-benthic transport model (SPBM): coupled simulation of ice, water column, and sediment biogeochemistry. Suitable Arct Appl Water 11:1582

Zhang R, Weinbauer MG, Qian P-Y (2007) Viruses and flagellates sustain apparent richness and reduce biomass accumulation of bacterioplankton in coastal marine waters. Environ Microbiol 9:3008-3018

Zhou J, Delille B, Kaartokallio H et al (2014) Physical and bacterial controls on inorganic nutrients and dissolved organic carbon during a sea ice growth and decay experiment. Mar Chem 166:59-69

Publisher's Note Springer Nature remains neutral with regard to jurisdictional claims in published maps and institutional affiliations. 